\title{
In vitro induction and identification of polyploid Neolamarckia cadamba plants by colchicine treatment
}

\author{
Wee-Hiang Eng ${ }^{1}$, Wei-Seng Ho ${ }^{\text {Corresp., } 1}$, Kwong-Hung Ling ${ }^{2}$ \\ 1 Faculty of Resource Science and Technology, Universiti Malaysia Sarawak, Kota Samarahan, Sarawak, Malaysia \\ 2 Sarawak Timber Association, Kuching, Sarawak, Malaysia \\ Corresponding Author: Wei-Seng Ho \\ Email address: wsho@unimas.my
}

Polyploidization has played a crucial role in plant breeding and crop improvement. However, studies on the polyploidization of tropical tree species are still very scarce in this region. This paper described the in vitro induction and identification of polyploid plants of Neolamarckia cadamba by colchicine treatment. N. cadamba belongs to the Rubiaceae family is a natural tetraploid plant with 44 chromosomes $(2 n=4 x=44)$. Nodal segments were treated with colchicine $(0.1 \%, 0.3 \%$ and $0.5 \%)$ for $24 \mathrm{~h}$ and $48 \mathrm{~h}$ before transferring to shoot regeneration medium. Flow cytometry (FCM) and chromosome count were employed to determine the ploidy level and chromosome number of the regenerants, respectively. Of 180 colchicine-treated nodal segments, 39, 14 and 22 were tetraploids, mixoploids and octoploids, respectively. The highest percentage of polyploidization $(20 \%$ octoploids; $6.7 \%$ mixoploids) was observed after treated with $0.3 \%$ colchicine for $48 \mathrm{~h}$. The DNA content of tetraploid (4C) and octoploid (8C) was $2.59 \pm 0.09 \mathrm{pg}$ and $5.35 \pm 0.24 \mathrm{pg}$, respectively. Mixoploid plants are made up of mixed tetraploid and octoploid cells. Chromosome count confirmed that tetraploid cell has 44 chromosomes and colchicineinduced octoploid cell has 88 chromosomes. Both octoploids and mixoploids grew slower than tetraploids under in vitro conditions. Morphological characterizations showed that mixoploid and octoploid leaves had thicker leaf blades, thicker midrib, bigger stomata size, lower stomata density, higher SPAD value and smaller pith layer than tetraploids. This indicates that polyploidization has changed and resulted in traits that are predicted to increase photosynthetic capacity of $N$. cadamba. These novel polyploid plants could be valuable resources for advanced $N$. cadamba breeding programs to produce improved clones for planted forest development. 


\section{In vitro induction and identification of polyploid} 2 Neolamarckia cadamba plants by colchicine treatment

4 Wee-Hiang Eng ${ }^{1}$, Wei-Seng $\mathrm{Ho}^{1 *}$ and Kwong-Hung Ling ${ }^{2}$

$5{ }^{1}$ Forest Genomics and Informatics Laboratory (fGiLab), Faculty of Resource Science and

6 Technology, Universiti Malaysia Sarawak, 94300 Kota Samarahan, Sarawak, Malaysia

8 2Sarawak Timber Association, Wisma STA, 26, Jalan Datuk Abang Abdul Rahim, 93450 Kuching,

9 Sarawak, Malaysia

*Corresponding author:

Wei-Seng Ho

Forest Genomics and Informatics Laboratory (fGiLab)

Faculty of Resource Science and Technology

Universiti Malaysia Sarawak

Email address:wsho@unimas.my 
26

\section{Abstract}

Polyploidization has played a crucial role in plant breeding and crop improvement. However, studies on the polyploidization of tropical tree species are still very scarce in this region. This paper described the in vitro induction and identification of polyploid plants of Neolamarckia cadamba by colchicine treatment. $N$. cadamba belongs to the Rubiaceae family is a natural tetraploid plant with 44 chromosomes $(2 n=4 x=44)$. Nodal segments were treated with colchicine $(0.1 \%, 0.3 \%$ and $0.5 \%$ ) for $24 \mathrm{~h}$ and $48 \mathrm{~h}$ before transferring to shoot regeneration medium. Flow cytometry (FCM) and chromosome count were employed to determine the ploidy level and chromosome number of the regenerants, respectively. Of 180 colchicine-treated nodal segments, 39, 14 and 22 were tetraploids, mixoploids and octoploids, respectively. The highest percentage of polyploidization (20\% octoploids; $6.7 \%$ mixoploids) was observed after treated with $0.3 \%$ colchicine for $48 \mathrm{~h}$. The DNA content of tetraploid (4C) and octoploid (8C) was $2.59 \pm 0.09 \mathrm{pg}$ and $5.35 \pm 0.24 \mathrm{pg}$, respectively. Mixoploid plants are made up of mixed tetraploid and octoploid cells. Chromosome count confirmed that tetraploid cell has 44 chromosomes and colchicineinduced octoploid cell has 88 chromosomes. Both octoploids and mixoploids grew slower than tetraploids under in vitro conditions. Morphological characterizations showed that mixoploid and octoploid leaves had thicker leaf blades, thicker midrib, bigger stomata size, lower stomata density, higher SPAD value and smaller pith layer than tetraploids. This indicates that polyploidization has changed and resulted in traits that are predicted to increase photosynthetic capacity of N. cadamba. These novel polyploid plants could be valuable resources for advanced $N$. cadamba breeding programs to produce improved clones for planted forest development. 
48 Keywords: Neolamarckia cadamba; Planted Forest, In Vitro Culture, Polyploidization,

49 Colchicine, Polyploid

50 Introduction

51 Neolamarckia cadamba (Roxb.) Bosser or Anthocephalus cadamba Roxb synonym is a fast-

52 growing multipurpose tree, self-pruning and growing vigorously in exploited areas, such as

53 logged-over forests and plantations (Krisnawati et al., 2011; Ho et al., 2014; Nordahlia et al., 2014;

54 Ho et al., 2020). It belongs to the Rubiaceae family and is a natural tetraploid plant with 44

55 chromosomes $(2 \mathrm{n}=4 \mathrm{x}=44)$ (Bedi et al., 1981; Kiehn \& Lorence, 1996; Puangsomlee \& Puff,

56 2001). It is a lightweight hardwood with a density of $290-560 \mathrm{~kg} / \mathrm{m}^{3}$ at $15 \%$ moisture content.

57 The wood has a moderately fine to medium texture that is easy to work with hand and machine

58 tools to give a perfect surface. This makes it an excellent raw material for plywood production,

59 light construction work and furniture manufacturing (Jøker, 2000; Lim \& Chung, 2002; Orwa et

60 al., 2009; Lal et al., 2010). It is also suitable for reforestation and enrichment planting schemes

61 (Krishnapillay et al., 2007). N. cadamba tree bark has also been used in traditional medicine to

62 treat various illnesses (Mondal et al., 2009). Despite being a commercially important commodity,

63 attempts to improve $N$. cadamba have been limited to gene mutation study using ethyl

64 methanesulphonate (EMS) (Zayed et al., 2014) and physical mutagens, such as gamma rays

65 (Zanzibar \& Danu, 2015). Mutation at ploidy level or polyploidization has yet to be studied.

66 Colchicine is an inhibitor to polymerization of the tubulin in nucleus that can cause

67 polyploidization in cells. It binds with $\beta$-tubulin in the microtubule, resulting in disassociation and

68 destabilization of the microtubule ( $\mathrm{Lu}$ et al., 2012). Microtubule enables translocation of

69 chromosomes during cell division (Hammond et al., 2008). The formation of polyploid is due to

70 the failure of chromosome pairs to separate during the anaphase of mitosis as mitosis ceases at 
71 metaphase. This will result in two sets of chromosomes in a single cell or the formation of 72 polyploid cells (Inoue, 1952; Eigsti \& Dustin, 1956). To date, colchicine is widely used in

polyploid induction with different explants, concentrations, treatment durations and methods (Hassan et al., 2020; Julião et al., 2020; Li et al., 2020; Zhang \& Gao, 2020). Polyploidization of tropical woody tree species has been rare due to slow-growing habits, long life cycles and lack of in vitro regeneration protocols.

The evolution and formation of new plant species are caused by natural and gradual adaptation to changing environments over a long period of time. Polyploidization increases the number of dominant alleles, diminishing the effects of recessive alleles that often result in undesirable traits (Comai, 2005; Soltis et al., 2015). This hypothesis makes polyploidization an attractive option for plant breeding to produce superior plants. Some induced polyploids were proven to adapt and tolerate better than their progenitors under undesirable or hostile environments. The induced tetraploid of Plumbago auriculata can tolerate cold environment at $5^{\circ} \mathrm{C}$ for $24 \mathrm{~h}$ (Jiang et al., 2020). In another study, the seed production of Themeda triandra tetraploid was quadrupled and heavier than its diploid under a very dry and hot arid environment (Godfree et al., 2017). The acquired "giga" effects in polyploids increase the size of the cells, followed by doubling in chromosome numbers (Sattler et al., 2016). This "giga" effect may contribute to greater agronomical gains in polyploid plants by producing larger organs like flowers, fruits, leaves, stems, roots, etc. The fruits of Actinidia chinensis tetraploid increase by $50-60 \%$ in size compared with those of the diploid (Wu et al., 2012), while in Thymus vulgaris tetraploid, an increase in the essential oil extracted from the plants was observed (Shmeit et al., 2020). Polyploidization is vital in the creation of triploid plants either within species or between species. Triploid plants are high in demand, especially in the fruit and vegetable industries where seedless 
94 fruits are produced (Sattler et al., 2016; Wang et al., 2016; Hassan et al., 2020). Furthermore, 95 triploids also exhibit heterosis or hybrid vigor (Fu et al., 2014; Urwin, 2014).

Flow cytometry (FCM) analysis is employed in the polyploid identification stage to 97 determine the ploidy level status and DNA content of regenerants treated with colchicine. FCM is an important procedure in polyploidization study where induced polyploids or mixoploids can be segregated from plantlets with unchanged ploidy levels (Bicknell et al., 2019; Huy et al., 2019; Julião et al., 2020). Mixoploidy exists due to incomplete polyploidization resulting in chimeric tissue comprising a mixture of tetraploid and octoploid cells. The cytometer used in FCM is a high throughput and reliable instrument where a large number of cells can be analyzed in a single run. The FCM, therefore, expedites the detection of representative population and subpopulation of the sample (Doležel et al., 2007; D’Hondt et al., 2011). However, FCM is not efficient in detecting aneuploidy. Therefore, a combination of FCM and karyotype examination is the best way to determine the number of chromosomes and ploidy level. Chromosome count is a straightforward, explicit and standard way of chromosome number determination. Chromosome count can also help to detect the creation of double haploids (Kim et al., 2019), interploids (de Alencar et al., 2020) and polyploids (Martin et al., 2019) in plant breeding. attempted through in vitro mutagenesis using colchicine. The polyploid plants were identified using FCM and validated using chromosome count followed by morphological characterization.

113 These newly induced polyploid plants may be beneficial for further genetic improvement of $N$. 114 cadamba to produce improved clones for planted forest development. To the best of our 115 knowledge, this is the first report of polyploidization in N. cadamba. 


\section{Materials and Methods}

\section{Nodal segments preparation and colchicine treatment}

119 Nodal segments were obtained from shoots regenerated from a selected $N$. cadamba seedling on 120 regeneration medium (B5 medium $+1.0 \mathrm{mgL}^{-1} \mathrm{BAP}+2 \%$ sucrose). The nodal segments were 121 treated with colchicine in different concentrations and durations, i.e., $0.1 \%, 0.3 \%$, and $0.5 \%$ of 122 colchicine for $24 \mathrm{~h}$ and $48 \mathrm{~h}$, respectively. In the control treatment, sterile distilled water was used 123 for $24 \mathrm{~h}$ and $48 \mathrm{~h}$. The nodal segments in the colchicine solution were incubated with shaking using 124 a platform shaker at $100 \mathrm{rpm}$ to improve contact between colchicine and explants. The whole 125 process of colchicine treatment was conducted in the dark at $25 \pm 2{ }^{\circ} \mathrm{C}$ to avoid deterioration of 126 colchicine under light.

\section{Flow cytometry analysis (FCM) and chromosome count}

The colchicine treated nodal segments of N. cadamba were subcultured for five cycles (four weeks per cycle) on shoot regeneration medium $\left(\mathrm{B} 5+1 \mathrm{mgL}^{-1} \mathrm{BAP}+2 \%\right.$ sucrose $)$ before the ploidy level determination. The fully developed in vitro young leaves from the control and colchicine treated plantlets were collected and used to determine the ploidy level. Untreated plantlets were used as control while Glycine max cv. Polanka was used as an external standard in FCM analysis (Doležel et al., 1989). About $1 \mathrm{~cm}^{2}$ of an in vitro young leaf for each sample was chopped in $1 \mathrm{ml}$ of lysis buffer or LB01 using a scalpel on the disposable petri dish. The LB01 buffer was made up of $80 \mathrm{mM} \mathrm{KCl}, 20 \mathrm{mM} \mathrm{NaCl}, 15 \mathrm{mM}$ Tris, $15 \mathrm{mM}$ mercaptoethanol, $2 \mathrm{mM} \mathrm{Na} 2 \mathrm{EDTA}, 0.5 \mathrm{mM}$ spermidine, 0.1\% Triton X-100, $\mathrm{pH} 7.5,50 \mu \mathrm{g}$ propidium iodide and $50 \mu \mathrm{g}$ RNase (Doležel et al., 1989). The finely chopped leaf pieces of each sample were filtered through a $50-\mu \mathrm{m}$ cell strainer separately into a $5 \mathrm{~mL}$ flow cytometry tube. The filtrate of each sample was analyzed by a 
140 FACSCalibur flow cytometer - Becton Dickinson equipped with an argon-ion laser (15 $\mathrm{mW})$ at $141488 \mathrm{~nm}$. Histograms for each sample were collected over 1,024 channels. DNA content of each 142 sample can be estimated using this formula (Doležel et al., 2007): $\mathrm{S}_{\mathrm{PL}}=\left(\mathrm{S}_{(\mathrm{G} 0 / \mathrm{G} 1)} / \mathrm{R}_{(\mathrm{G} 0 / \mathrm{G} 1)}\right) \times \mathrm{R}_{\mathrm{PL}}$, 143 where $\mathrm{S}_{\mathrm{PL}}$ is $2 \mathrm{C}$ value of colchicine treated sample; $\mathrm{R}_{\mathrm{PL}}$ is $2 \mathrm{C}$ of the control sample, i.e., Glycine $144 \max$ Merr. 'Polanka' with a value 2.50; $\mathrm{S}_{(\mathrm{G} 0 / \mathrm{G} 1)}$ means the position of colchicine treated sample, 145 and $\mathrm{R}_{(\mathrm{G} 0 / \mathrm{G} 1)}$ means the position of control sample peak.

146 The 5-day-old in vitro root tips after transplantation were excised at $1 \mathrm{~cm}$ in length from 147 the tip of the roots. The root tips were washed with running tap water to eliminate the agar medium. 148 In pre-treatment, these root tips were first submerged in $0.002 \mathrm{M}$ 8-hydroxyquionline for $2 \mathrm{~h}$ at 4 ${ }^{\circ} \mathrm{C}$ followed by another $2 \mathrm{~h}$ at room temperature. The pre-treated root tips were washed three times with distilled water. In fixation, the root tips were dipped in freshly prepared cold Carnoy's solution 1 (Ethanol 95\% : glacial Acetic Acid; $3: 1$ ) for 24 h at $4{ }^{\circ} \mathrm{C}$. After fixation, the root tips were washed with distilled water three times. The hydrolysis of the pre-treated and fixed root tips took place using $1 \mathrm{~N} \mathrm{HCl}$ for $15 \mathrm{~min}$ at $60{ }^{\circ} \mathrm{C}$. After $\mathrm{HCl}$ hydrolysis, the root tips were washed with distilled water three times. The staining process was carried out at room temperature. Feulgen stain was applied on the root tips for $30 \mathrm{~min}$ in dark condition before squashing with a metal bar in a drop of aceto-orcein 1\% stain followed by thumb squash (Eng et al., 2020).

157

\section{In vitro propagation and acclimatization}

In vitro nodal segments were excised from $N$. cadamba tetraploid, mixoploid and octoploid plantlets and cultured on shoot regeneration medium $\left(\mathrm{B} 5+0.8 \mathrm{mgL}^{-1} \mathrm{BAP}+2 \%\right.$ sucrose $)$ for six weeks with subculture once every three weeks. The number of shoots produced and the percentage of nodal segments producing shoots were recorded. After regeneration, well-developed shoots, 
163 about $1 \mathrm{~cm}$ in height, of the tetraploid, mixoploid and octoploid cultures were excised from the

164 shoot clumps and transferred to basal B5+ 2\% sucrose medium for eight weeks with subculture

165 once every four weeks. Morphological characters of tetraploid, mixoploid and octoploid shoots

166 were recorded, namely plant height, number of leaves, number of nodes and stem diameter after

167 eight weeks of culture. The shoots of the tetraploid, mixoploid and octoploid cultures with the

168 height of $3.0 \mathrm{~cm}$ were excised and cultured on rooting medium, $1 / 2 \mathrm{~B} 5+0.1 \mathrm{mgL}^{-1} \mathrm{PBZ}$

169 (Paclobutrazol) $+2 \%$ sucrose. The number of roots and the percentage of rooting were recorded

170 after two weeks of culture. Well rooted in vitro plantlets were cleaned thoroughly under running

171 tap water before planted onto different acclimatization media. These acclimatization media are

172 Jiffy-7, loamy soil and soil mixture (loamy soil : compost $=3: 1$ ). The Jiffy-7 pellets were soaked

173 in tap water overnight before use. Both the loamy soil and the soil mixture were sterilized by

174 autoclaving at $121^{\circ} \mathrm{C}$ for $20 \mathrm{~min}$. All transferred plantlets were kept in air-tight containers for the

175 first week before the container's covers were removed gradually to regulate humidity and avoid 176 plantlets from wilting. Plantlets were maintained under room temperature. Fungicide was applied

177 weekly to prevent fungal contamination among the acclimatizing plantlets. The number of

178 surviving plantlets in different media was recorded after four weeks of acclimatization.

179 This experiment consisted of tetraploid, mixoploid and octoploid plantlets; each genotype 180 consisted of six plantlets, and the experiment was repeated thrice. The data collected were 181 subjected to ANOVA using the IBM SPSS version 23 program. The ANOVA was carried out first, 182 followed by Duncan New Multiple Range Test (DNMRT) $(\mathrm{p}<0.05)$. 
185 The well-developed third leaf from the shoot tip of one-month-old acclimatized seedlings was 186 obtained for leaf and midrib thickness studies. Using a razor blade, cut across the width of the leaf

187 sample about $1 \mathrm{~mm}$ wide. The leaf section was placed on a slide vertically with the cut section 188 facing upwards. The leaf section was observed using a LEICA DM500 compound light microscope 189 4x objective lens. The image of the leaf section was captured using a LEICA ICC50 HD camera. 190 LEICA Application Suite (LAS EZ) was used to measure the leaf and midrib thickness. A total of 19110 leaves for each genotype was analyzed, namely tetraploid, mixoploid and octoploid to 192 determine leaf and midrib thickness.

The well-developed leaves of acclimatized seedlings were obtained for abaxial leaf study.

A layer of clear nail polish was painted on the abaxial leaf side and leave it to dry. Then a pair of tweezers was used to peel the nail polish from the leaf surface. Place the nail polish peel with leaf impression on a slide. The leaf surface was observed using a LEICA DM500 compound light microscope 40x objective lens, and the image was captured using a LEICA ICC50 HD camera. A total of 100 stomata was measured for each genotype, namely tetraploid, mixoploid and octoploid. LEICA Application Suite (LAS EZ) was used to measure the length and width of the stomata. Ten optical micrographs $(0.33 \times 0.25 \mathrm{~mm})$ were used to determine the density of the stomata and trichomes. ImageJ software was used to determine the number of stomata and trichomes per $\mathrm{mm}^{2}$. Scanning electron microscope (SEM) was used to examine the structure and other details of the stoma and trichomes. Initially, six-month-old leaves were sectioned using a blade, and only the middle part of the leaf sections was used for the SEM study. Leaf samples were prepared using the protocol developed by Talbot and White (2013). The leaf sections were fixed in $100 \%$ methanol for $10 \mathrm{~min}$. After the fixation, they were dehydrated two times in $100 \%$ methanol for 30 min before

207 further dried using a critical point drying machine. The leaf sections were mounted on SEM stud 
208 with the abaxial part facing upwards. The samples were then coated with gold coatings before they

209 were observed using SEM by JEOL model JSM-6390OLA.

A mature stem from a one-year-old plant was cut using a fine tooth saw to study the cross-

211

212

213

214

215

216

217

218

219

220

221

222

223

224

225

226

227

228

229

230

section of the 10-month-old stem. The thickness of bark, pith and wood of $N$. cadamba were recorded with the aid of a pair of vernier calliper. A total of three stem section for each genotype were analysed, namely tetraploid, mixoploid and octoploid.

The leaf SPAD values were measured using portable chlorophyll meter, model TYS-B (Mindfull Technology Co. Ltd) that was equipped with two light sources, namely red light (650 $\mathrm{nm})$ and infrared light $(940 \mathrm{~nm})$. To measure SPAD value, grip the leaf sample between the pressure head and measuring head of the meter. The buzzer of this meter will buzz for less than 3 seconds signalling the measurement is completed and the reading can be recorded. A total of 30 trees consisting of tetraploid, mixoploid and octoploid plants were measured, and each genotype consisted of 10 plants.

The data collected were subjected to ANOVA using the IBM SPSS version 23 program. The ANOVA was carried out first, followed by Duncan New Multiple Range Test (DNMRT) (p $<0.05)$.

\section{Results}

\section{Flow cytometry analysis (FCM) and chromosome count}

In all colchicine treatments $(0.1 \%, 0.3 \%$ and $0.5 \%)$, the longer treatment duration at $48 \mathrm{~h}$ tend to produce a higher number of octoploids and a lower number of mixoploids (Table 1). In total, 39 tetraploids, 14 mixoploids and 22 octoploids were produced in this study. Two treatments, namely $0.3 \%$ colchicine for $48 \mathrm{~h}$ and $0.5 \%$ colchicine for $48 \mathrm{~h}$ gave higher percentages (20\%) of 
231 octoploids. However, treatment with $0.3 \%$ colchicine for $48 \mathrm{~h}$ produced the best result that yielded

$23220.0 \%$ octoploids and $6.7 \%$ mixoploids. In the $0.3 \%$ colchicine treatment for $24 \mathrm{~h}$, the highest

233 percentage of mixoploids was obtained. Generally, a combination of a higher concentration of

234 colchicine and a longer treatment duration yielded a higher percentage of octoploids in $N$.

235 cadamba. The ploidy level of regenerants of $N$. cadamba can be determined based on the histogram

236 generated using a flow cytometer (Figures 1A-1C). The histogram showed a single dominant peak

237 in control and tetraploid plants with the mean position of a peak for 4x (Figure 1A). For the

238 mixoploid plants, the histogram showed two separate dominant peaks with the mean position of

239 the first peak for $4 \mathrm{x}$ and the mean position of the second peak for 8x (Figure 1B). For the octoploid

240 plants, the histogram showed a single dominant peak with the mean position of a peak for $8 \mathrm{x}$

241 (Figure 1C). It was also noted that the octoploid cells (Figure 1C) are two times greater in the mean

242 position of the peak than those of the tetraploid cells (Figure 1A). Our data showed that the

243 estimated DNA content for tetraploid (4C DNA) is $2.59 \pm 0.09 \mathrm{pg}$, while for octoploids, there is a

244 two-fold increase in the estimated DNA content $(8 \mathrm{C}$ DNA $=5.35 \pm 0.24 \mathrm{pg})$.

245 The ploidy level of samples determined using FCM was verified using the optimized

246 chromosome count procedure. The micrograph of the somatic cells of $N$. cadamba root tips showed

247 that both the tetraploid and the control contain 44 chromosomes per nucleus (Figure 1D); the

248 octoploid (a.k.a N. cadamba “Kestamas-19”) contains 88 chromosomes per nucleus (Figure 1E),

249 while the mixoploid contains either 44 or 88 chromosomes per nucleus. The ploidy level results

250 determined using the FCM procedure agree with results obtained using the optimized chromosome

251 count method.

252

253 In vitro propagation and acclimatization 
254 The shoot regeneration ability between the tetraploid, mixoploid and octoploid was observed and 255 compared with each other (Table 2). The mean number of shoots produced was significantly higher 256 in the tetraploid (5.4) as compared to mixoploid (4.3) and octoploid (4.2) (Table 2). In terms of 257 the mean percentage of explants producing shoots, the tetraploid (94.4\%) and mixoploid (100.0\%) 258 showed significantly higher mean percentages of explants producing shoots compared to the 259 octoploid (83.3\%). The new genotypes of $N$. cadamba, i.e., the mixoploid (Figure 2B) and 260 octoploid (Figure 2C) showed significantly lower achievement in terms of the number of shoots 261 produced as compared with the tetraploid (Figure 2A). The octoploid responded with the lowest 262 mean percentage of regeneration among the three genotypes (Table 2). The observation from this

263 264

study concluded that polyploidization resulted in higher mortality in the shoot regeneration medium.

The growth of $N$. cadamba tetraploid, mixoploid and octoploid shoot tips on the basal B5 medium was evaluated after they have been transferred from the regeneration medium. After eight weeks of growth on the basal B5 medium, the tetraploid attained the highest mean plant height at $7.2 \mathrm{~cm}$, followed by the mixoploid at $6.8 \mathrm{~cm}$ and the octoploid at $4.4 \mathrm{~cm}$ only (Table 2). Polyploidization in N. cadamba has noticeably reduced the plant height (Table 2 and Figure 2D). There was no significant difference between the tetraploid, mixoploid, and octoploid shoots in terms of the mean number of leaves and the mean number of nodes. The mean number of leaves ranges from 12.8 to 13.0 , while the mean number of nodes ranges from 6.4 to 6.5 for tetraploid, mixoploid and octoploid (Table 2). The octoploid plantlets have shorter stems making each of them an interestingly compact architecture (Figure 2D). The mean stem thickness of the shoots in tetraploid was $2.3 \mathrm{~mm}$ only, while the octoploid $2.89 \mathrm{~cm}$ and mixoploid $2.7 \mathrm{~mm}$. The stem of the two new polyploids was significantly thicker than the tetraploid (Table 2). From the in vitro growth 
277 parameters recorded, polyploidization resulted in the reduction of stem height but has the opposite

278 effect of increment in stem diameter. The octoploids are sturdier than mixoploid and tetraploid

279 plantlets due to their shorter stems.

280 The excised shoots of tetraploid, mixoploid and octoploid of N. cadamba were cultured in

281 rooting medium for 14 days to compare the rooting capability of plantlets of different ploidy levels

282 (Table 2 and Figures 2E-2G). All shoots, regardless of ploidy level, produced roots after the 14

283 days on rooting medium. The tetraploid (13.8) and mixoploid (16.1) produced a higher mean

284 number of roots compared with the octoploid (11.1). In terms of mean root length, the tetraploid

285 produced the longest mean root length $(1.8 \mathrm{~cm})$, followed by the mixoploid $(1.6 \mathrm{~cm})$ and octoploid

$286(1.4 \mathrm{~cm})($ Table 2$)$. In this study, the shoots were cultured on the rooting medium for no longer

287 than 14 days to avoid excessive rooting, leading to a high number of roots and longer root length.

288 The rooted plantlets were transferred to three different media types, namely Jiffy-7, loamy

289 soil, soil mix (loamy soil : compost; $3: 1$ ) to assess the percentage of acclimatization of the

290 plantlets (Figure 2H). The mean percentage of acclimatization of the tetraploid plantlets planted

291 on Jiffy-7 pellets and loamy soil was $94.4 \%$ and $88.9 \%$, respectively. These two media types were

292 significantly superior to the soil mix that produced only $50.0 \%$ mean percentage of acclimatization.

293 A similar trend was observed in the mixoploid and octoploid plantlets (Table 2). Two factors that

294 caused mortality to the $N$. cadamba plantlets during acclimatization were water stress and fungal

295 contamination. Water stress can be controlled by placing plantlets in an enclosed container to maintain higher humidity and prevent water loss. In this study, $5 \mathrm{gL}^{-1}$ Benocide solutions were sprayed with a mist sprayer. Incorporating compost in the soil mix should be avoided in this experiment as it would encourage fungal contamination even after autoclaving before planting. 


\section{Morphological characteristics and SPAD value}

301 The $N$. cadamba octoploid $(247.2 \mu \mathrm{m})$ had thicker leaves than its tetraploid counterpart (160.8

$302 \mu \mathrm{m})$. However, there was no significant difference in mean leaf thickness between the mixoploid

303 and tetraploid. The mean midrib vertical thickness of the octoploid $(831.7 \mu \mathrm{m})$ was higher than

304 both the mixoploid $(762.4 \mu \mathrm{m})$ and tetraploid $(666.6 \mu \mathrm{m})$. The mean midrib horizontal thickness

305 of the octoploid $(899.1 \mu \mathrm{m})$ and the mixoploid $(793.0 \mu \mathrm{m})$ was higher than the tetraploid $(616.2$

$306 \mu \mathrm{m})$. However, there was no significant difference between the mixoploid and the tetraploid in

307 terms of mean midrib vertical thickness (Table 3 and Figures 3A-3C).

308 The mean stomata density per $\mathrm{mm}^{-2}$ in octoploid (301.8) and mixoploid (298.2) were

309 significantly less than the tetraploid (426.7) of N. cadamba plants (Table 3 and Figures 3D-3F).

310 Similarly, the mean trichome density $\mathrm{mm}^{-2}$ was significantly less in octoploid (4.9) and mixoploid

311 (4.9) when compared with the tetraploid (33.9) of $N$. cadamba plants. The mean stomata length of

312 either the mixoploid $(29.3 \mu \mathrm{m})$ or octoploid $(30.7 \mu \mathrm{m})$ was higher than the tetraploid $(25.3 \mu \mathrm{m})$.

313 The mean stomata width of either the mixoploid $(16.1 \mu \mathrm{m})$ or octoploid $(16.6 \mu \mathrm{m})$ was also higher

314 than the tetraploid $(14.9 \mu \mathrm{m})$. Generally, the mixoploid and octoploid plants of N. cadamba possess

315 a bigger stomata size than the tetraploid plant (Table 3 and Figures 3G-3I). The stoma of $N$.

316 cadamba tetraploid, mixoploid and octoploid was then observed using SEM at 2000x. The

317 micrograph showed that regardless of ploidy level, the stoma is made up of two complementary

318 kidney-shaped guard cells arranged in opposite sites to form an aperture. Each guard cell is flanked

319 by a subsidiary cell that aligns parallel to its long axis. The trichomes of $N$. cadamba in this study

320 were observed using SEM at 2000x. The micrograph showed, regardless of ploidy level, the

321 trichomes were categorized as unicellular and non-glandular trichomes (Figures 3J-3L) based on

322 trichomes anatomical categorization by Werker (2000) study. The shape and other attributes of $N$. 
323 cadamba trichome are categorized as ornithorhynchous based on the nomenclatures determined

324 by Payne (1978).

325 In the stem cross-section study, the bark, wood and pith layers of $N$. cadamba plants were

326 studied. There was no significant difference between the tetraploid, mixoploid and octoploid in the

327 bark and wood layers. However, the tetraploid $(5.7 \mathrm{~mm})$ and mixoploid $(5.2 \mathrm{~cm})$ have a bigger

328 pith than the octoploid (3.6 $\mathrm{mm})$ (Table 3 and Figure $3 \mathrm{M})$.

329 The mean SPAD value of the octoploid was the highest (39.7) when compared to the 330 mixoploid (37.2) and tetraploid (37.1). Hence, the chlorophyll content of the octoploid was also 331 higher than both the mixoploid and tetraploid (Table 3).

333 Discussion

Flow cytometry analysis (FCM) and chromosome count

335

336

337

338

339

340

Colchicine is a commonly used chromosome doubling agent. Its anti-mitotic properties result in the disruption of microtubules to produce polyploids. Polyploids induced by using colchicine are also termed as colchiploids. This term was widely used in 1960's (Sen \& Marimuthu, 1960; Raghuvanshi \& Joshi, 1964; Das et al., 1970). The optimum amount of colchicine used in polyploid production is wide-ranging, with concentrations ranging from $0.001 \%$ (Thao et al., 2003 ) to $1.0 \%$ (Demtsu et al., 2013). The difference is one hundred times between the highest and the lowest colchicine concentration. The percentage of successful polyploidization also varies. The success rate could be attributed to the species under investigation, the colchicine application protocol (in vitro or ex vitro) and the explant used.

FCM can detect the existence of mixoploids and it can analyze a huge population of cells in a relatively short duration. In the histogram generated from FCM for N. cadamba, Figure 1c, 
346 two distinct populations of cells were detected, namely $4 \mathrm{x}$ and $8 \mathrm{x}$, and this finding can be

347 interpreted from the two dominant peaks in the histogram. Polyploidization studies conducted

348 without the FCM procedure often yielded very high polyploidization percentage but no occurrence

349 of mixoploids, such as $100 \%$ for Pogostemon cablin leaves (Widoretno, 2016), 42.3\% for

350 Gossypium arboretum seeds (Yang et al., 2015) and 41.7\% for Vitis sp. (Sinski et al., 2014) shoot

351 tips. These studies determined polyploidization through manual chromosome counting, which is

352 difficult because the researcher has to analyze a huge number of cells needed to represent an

353 accurate cell composition of the plant. Studies on polyploidization using seeds, seedlings, shoot

354 tips, and nodal segments are predominantly prone to the production of mixoploids which is an

355 unwelcome result (Eng \& Ho, 2019). Studies using these sources of explants should adopt FCM

356 to avoid mixoploids being pooled into induced polyploids or the original ploidy category. FCM

357 will help the researcher to identify the mixoploids. The existence of mixoploids will often mislead

358 the analysis leading to a possible inaccurate conclusion.

359 According to Ohri et al. (2004), the estimated 4C DNA for $A$. cadamba was $2.77 \pm 0.27 \mathrm{pg}$

360 using M86 Vickers microdensitometer. The data have been published and archived in the C-value

361 Kew Garden database (http://www.kew.org/cval/homepage.html), where the data are conveyed in

362 estimated 1C DNA, that is $0.69 \mathrm{pg}$. These data showed that N. cadamba is a tetraploid. Based on

363 these data, our estimated 4C DNA of $N$. cadamba was $2.59 \pm 0.09 \mathrm{pg}$, which falls within the

364 published data range, while the octoploids estimated 8C DNA was $5.35 \pm 0.24 \mathrm{pg}$. This study

365 indicated that the DNA content had doubled in $N$. cadamba tetraploid to form N. cadamba

366 octoploid. There are many uses of estimated DNA content apart from the indication of ploidy level

367 change. According to Bennett et al. (2000), estimated DNA content could be used in the molecular 
368 investigation, evolution, variation, constancy, phylogenetic, phenotypic, phenological, ecological, 369 environmental indicators, and paleobiological trends.

According to Regalado et al. (2017), mixoploid plants are unstable as competition occurs

371

372

373

374

375

376

377

378

379

381

382

384

385

386

387

388

389

390 between the original cells and the polyploid cells leading to the elimination of the latter. As a result, mixoploids status will be reversed to its original ploidy level. In citrus breeding, mixoploids were discarded due to stability concern and low fertility if crossed with other species (Grosser et al., 2014). For this study, N. cadamba mixoploids produced were maintained and further evaluated together with tetraploids and octoploids. Mixoploids are often regarded as a failure or undesirable by-products of polyploidization studies so that efforts are made to eliminate them through deliberate means, namely mechanical isolation of putative polyploids (Aleza et al., 2009; Regalado et al., 2015); shoot regeneration using nodal segments (Zhou et al., 2017) and repeated subcultures of apical buds (Jiang et al., 2020).

The chromosome count enables the verification of samples determined using FCM. In the present study, the FCM results using leaf samples aligned with our findings through the chromosome count using root tip samples. The control, which is a tetraploid $(2 n=4 x)$ contains 44 chromosomes per nucleus, the octoploid $(4 n=8 x)$ contains 88 chromosomes per nucleus and the mixoploid $(2 n+4 n=4 x+8 x)$ contains either 44 or 88 chromosomes per nucleus. This study, based on the chromosome count, has verified the ploidy level data obtained from FCM. The polyploidization of $N$. cadamba using colchicine has successfully induced octoploids and mixoploids from tetraploid explants. The chromosome number of $N$. cadamba $(2 \mathrm{n}=4 \mathrm{x})$ has doubled $(4 n=8 x)$ after colchicine treatment (Figures 1D and 1E). This is a two-fold increment of chromosome number from the original N. cadamba explant. This is the first establishment of $N$. cadamba octoploid ever reported, where the chromosome number is 88 .

Peer] reviewing PDF | (2021:06:62624:1:0:NEW 15 Sep 2021) 


\section{In vitro propagation and acclimatization}

393

394

395

396

397

398

399

400

401

402

403

404

405

406

407

408

409

410

411

412

413

In vitro technique was used in this study to examine the effects of $N$. cadamba polyploid plants at different stages of micropropagation following the established tissue culture protocol of $N$. cadamba (Mok \& Ho, 2019). With these advantages, mass phenotyping and characterizing of new plants are now a possible task. Our study is in agreement with that of the induced polyploid plants of Cichorium intybus (Ravandi et al., 2014) and Dendrobium officinale (Pham et al., 2019). The explants of induced polyploid of $D$. officinal produced a higher protocorm induction rate but required a longer time for protocorm initiation. According to Ravandi et al. (2014), the ability to regenerate shoots from callus or organogenesis in induced polyploid explants was significantly reduced. Tsukaya (2008) reported that Arabidopsis thaliana with more than eight sets of homologous chromosomes will display high ploidy syndrome, exhibiting contrasting effects by producing bigger cell in volume but smaller leaves. Several recent studies have employed the in vitro system to study the effects of plant ploidy level on morphological traits (Javadian et al., 2017; Pham et al., 2019; Shmeit et al., 2020). The present study is in agreement with Pham et al. (2019), where colchicine-induced tetraploids of $D$. officinale showed shorter stem length and thicker stem. The thicker stem was also found in the colchicine-induced tetraploid of Linum album (Javadian et al., 2017). However, oryzalin-induced tetraploid of Thymus vulgaris showed longer stem length and thicker stem (Shmeit et al., 2020).

The induced octoploid of $N$. cadamba exhibited slower root formation. The root growth was also slower in the rooting medium (Table 2 and Figures 2E-2G). According to Mok and Ho (2019), the rooting medium $1 / 2 \mathrm{~B} 5+0.1 \mathrm{mgL}^{-1} \mathrm{PBZ}$ is an optimum medium in inducing a sufficient number of roots in N. cadamba. The PBZ concentration does not affect growth during the rooting, 
414 and there is no callus formation on the shoot. The protocol has improved the success rate of 415 acclimatization. PBZ derived from an aromatic compound, trizol is a plant growth regulator with 416 many uses in agriculture. Among others, it is used to induce flowering, fruiting and prevent fungal 417 infections (Wang et al., 2019). PBZ has many uses in in vitro culture for different plants, such as 418 shoot multiplication medium MS $+5 \mathrm{mgL}^{-1}$ in Phoenix dactylifera (Awadh et al., 2019), rooting 419 medium 1/2 B5 $+0.1 \mathrm{mgL}^{-1}$ in $N$. cadamba (Mok \& Ho, 2019) and rooting medium MS +1.5 $420 \mathrm{mgL}^{-1}$ in Zygopetalum crinitum (Gimenes et al., 2018).

Acclimatization is the final stage of in vitro system that will determine the production number of the plantlets. In vitro acclimatization depends on the capability of the plantlets to transform from being either mixotrophic or heterotrophic to photoautotrophic before they can adapt to the harsh ex vitro conditions. Plantlets in in vitro system are mixotrophic or heterotrophic where complete nutrients are provided to sustain growth, while plantlets under ex vitro conditions need to become photoautotrophic where foods can be synthesized through photosynthesis 427 (Debergh, 1991; Pospíšilová et al., 1999; Chandra et al., 2010). With this principle in mind, in vitro plantlets of $N$. cadamba of different ploidy levels were acclimatized using different media types while controlling humidity and preventing fungal contamination. There was no significant difference between Jiffy-7 pellet and loamy soil to produce higher numbers of acclimatized plantlets than soil mix of loamy soil : compost; $3: 1$ (Table 2 and Figure $2 \mathrm{H}$ ). As the loamy soil can be locally sourced, it is more plentiful and cheaper than the Jiffy-7 pellet and, therefore, should be used as the main medium for acclimatization. Loamy soil provides adequate nutrients to sustain the growth of the plantlets apart from acclimatizing. The addition of compost into the loamy soil does not contribute to better growth or more successful acclimatization of the plantlets at the acclimatization stage. This study agrees with Mok and Ho (2019), where Jiffy-7 provides a high 
437 percentage of successful acclimatization. Jiffy-7 pellet is only made of compressed peat moss and

438 coco fibers in the fine net that provides adequate aeration water. Mengesha et al. (2013) obtained

439 a similar result where Jiffy-7 pellet was found to improve not only acclimatization of in vitro

440 plantlets of Ananas comosuss but also the growth during acclimatization.

The approach to humidity control in this study during acclimatization was similar to the

442 method described by Ahmed et al. (2012). Newly deflasked plantlets of $N$. cadamba are

443 susceptible to water stress and low humidity. The newly transplanted plantlets were placed in a

444 clear, air-tight container to maintain high humidity. The container cover was removed slowly to

expose the plantlets progressively to ex vitro conditions. Adapting the plantlets slowly to ex vitro

conditions can prevent abiotic stress to the plantlets, which is the main cause of mortality.

According to Chandra et al. (2010), high humidity in in vitro culture vessels can impair the

to excessive transpiration when the plantlets are transferred to ex vitro environment with low phenomenon or rainfall (Mansur \& Tuheteru, 2010). Therefore, regular watering is essential as the on either the roots, leaves or stems of the plantlets. The plantlets were misted with $5 \mathrm{gL}^{-1}$ Benocide solution weekly using a mist sprayer to reduce fungal infections.

457 Morphological characteristics and SPAD value

This study observed that the octoploid and mixoploid plants of $N$. cadamba produced thicker leaf than the tetraploid plants (Table 3 and Figures 3A-3C). This characteristic is in line with several 
460 other induced polyploid species, such as Anthurium andraeanum (Chen et al., 2011); Lobularia

461 maritima (Huang et al., 2015); Lycium rhuthenicum (Rao et al., 2019); Manihot esculenta (Zhou

462 et al., 2017); Bacopa monnieri (Inthima \& Sujipuli, 2019); Plumbago auriculata (Jiang et al.,

463 2020) and Solanum lycopersicum (de Alencar et al., 2020). Detailed histological study on $S$.

464 lycopersicum leaf blade revealed that thicker leaf in the induced polyploid was the result of greater

465 thickness in the epidermis (adaxial and abaxial) and the parenchyma (spongy and palisade) layers

466 (de Alencar et al., 2020). In the induced polyploid of Plumbago auriculata, the histological study

467 showed that thicker spongy tissue contributed to thicker leaf(Jiang et al., 2020). These histological

468 studies reveal the thicker leaf compositions but do not provide further information regarding the

469 function of the thicker leaf in plants.

470 There is much empirical evidence showing that plants with thicker leaves have better

471 adaptability to a drier environment. According to Afzal et al. (2017), plant species with thicker

472 leaves can withstand greater drought and salinity. They also stated that leaf thickness assessment

473 is a promising technique to predict water status in plants. In another study, under arid conditions,

474 plants with thicker leaves can adapt by maintaining water potential when the water source is

475 limited (Ogburn \& Edwards, 2010). A thicker leaf is associated with the plant ability to inhabit

476 and adapt to challenging environments like arid conditions and high irradiance (Li et al., 2014;

477 Coneva \& Chitwoo, 2018). A plant can adapt to a harsh environment inflicted by climate change

478 by modifying leaf morphological and anatomical traits (Dar et al., 2013; Soudzilovskaia et al.,

479 2013; Tian et al., 2016; Ribeiro et al., 2016; Souza et al., 2018). Inferring from the evidence as

480 stated, thicker leaf of $N$. cadamba plants acquired through polyploidization may similarly be more

481 adaptable to a drier condition, such as in locations with lower rainfall. This improvement is

482 essential to N. cadamba due to looming climate change exacerbated by global warming. 

progenitor (Table 3 and Figures 3A-3C). This is in line with the finding of the polyploidization study of Salix viminalis by Dudits et al. (2016), where induced tetraploid plants were reported to have thicker midrib. This could increase water volume transported to the leaf blade where more water can be stored to prevent the plant from excessive water loss during drought. Furthermore, thicker leaf midrib provides a stronger leaf structure of N. cadamba that may prevent the leaf blade from wind damage.

Stomata morphology is commonly used to determine how polyploidization has modified 491 the characteristics of the polyploid due to its ubiquity, homology across distantly related relatives and uniform shape (Doyle \& Coate, 2019). This makes stomatal study reliable and repeatable when different leaf samples are used, apart from the relatively easier and faster (Xie et al., 2015; Eng \& Ho, 2019). Polyploidization of plants always produces bigger stomata size and lesser stomata density (number of stomata per unit area) at the abaxial side of the leaf of different species such as Impatiens walleriana (Ghanbari et al., 2019); Dendrobium officinale (Pham et al., 2019); Lycium ruthernicum (Rao et al., 2019); Paphiopedilum villosum (Huy et al., 2019); and Plumbago auriculata (Jiang et al., 2020). These characteristics can also be observed in N. cadamba in this study, where octoploid and mixoploid plants pose bigger stomata in terms of mean length and mean width and lower mean stomata density compared to their tetraploid progenitor (Table 3 and Figures 3D-3F). A negative correlation between stomata size and stomata density is common in 502 the leaves (Camargo \& Marenco, 2011; Doheny-Adams et al., 2012; Bertolino et al., 2019). This 503 contrasting characteristic is called plastic developmental responses to evolutionary adaptation and 504 environmental changes (de Boer et al., 2016; Dittberner et al., 2018). 

plants of $N$. cadamba (Figures 3G-3I). The N. cadamba stomata belong to the paracytic type, where

507

508

509

510

511

512

513

514

515

516

517

518

519

520

521

522

523

524

525

526

527

each guard cell is accompanied by a subsidiary cell to its long axis (Willmer \& Fricker, 1996).

This stomata type is typical to members of the Rubiaceae family. Most water obtained in plants is transpired through stomatal apertures before being utilized for plant growth. The ability to conserve water and use it efficiently will improve plant growth. Stomata characteristics, such as size and density, play an essential role in determining water-use-efficiency in the crop, thus making these characteristics essential to crop improvement target (Bertolino et al., 2019). Under a controlled atmosphere, Arabidopsis thaliana mutant plants with lower stomatal density are better adapted to the higher concentration of atmospheric $\mathrm{CO}_{2}$ and water-scarce environment (DohenyAdams et al., 2012). This finding suggested that genetically modified plants with lower stomatal density can be better adapted to predicted future climate change where elevated atmospheric $\mathrm{CO}_{2}$ and more arid land become more prevalent. Recent research has also shown that genetically engineered crops with reduced stomatal density may contribute to better water usage efficiency and drought tolerance without productivity decline (Bertolino et al., 2019). Given much evidence, induced octoploid and mixoploid of $N$. cadamba with reduced stomata density and increased stomata size are likely to attain a greater advantage in utilizing water resources in the field.

Polyploidization of $N$. cadamba caused significantly reduced trichome density of mixoploid and octoploid plants than their tetraploid progenitor plants. However, the trichome size of mixoploid and octoploid plants were relatively bigger than tetraploid plants (Table 3, Figures 3J-3L). This finding is in line with Zhang and Gao (2020), where trichomes density on leaf sheath of Dendrobium cariniferum has reduced in the induced tetraploid plant compared with the diploid progenitor plant. The trichomes play a vital role in protecting the plant from biological and 
528 environmental hazards, namely herbivores, pathogens, excessive ultraviolet irradiation and over

529 transpiration (Xiao et al., 2017). The characterization and classification of trichomes are

530 challenging due to the immense diversity of trichomes in morphology, origin, size, location,

531 surface microstructure, secretory organ, function and timing of activity. However, the main

532 characteristic is glandular or non-glandular (Werker, 2000). The trichomes of the tetraploid,

533 mixoploid and octoploid of $N$. cadamba are categorized as non-glandular and unicell trichomes.

534 The shapes and attributes of the trichomes have been described in detail by Payne (1978) and the

535 trichomes of $N$. cadamba polyploid plants are termed as ornithorhynchous, which resembles a

536 bird's bill (Figures 3J-3L).

Stem cross-section of $N$. cadamba showed that the pith of either the tetraploid or mixoploid

538 was significantly bigger than that of the octoploid (Table 3 and Figure $3 \mathrm{M}$ ). However, there is no 539 significant difference for wood and bark layers of tetraploid, mixoploid and octoploid plants. The 540 smaller pith in the octoploid is an improvement to the stem of $N$. cadamba, which may be of 541 importance to wood production. The pith in $N$. cadamba will eventually dry up as the tree ages or 542 after harvesting. The stem cross-section study is destructive as the plant has to be sacrificed to 543 reveal the stem composition. Stem cross-section has rarely been studied in the polyploidisation of 544 plants. The stem cross-section study is important to those trees that are used for timber production 545 and where the quality and quality of the timber are desired. In the Salix viminalis polyploidization 546 study, the induced tetraploid plants have a significantly greater composition of bark and wood 547 layers than the tetraploid plants (Dudits et al., 2016). content (Wang et al., 2017; Rao et al., 2019). Our study is in line with both studies showing induced polyploid plants of $N$. cadamba gain a higher mean SPAD value than their progenitor 
551 (Table 3). SPAD value correlates positively to the chlorophyll content and greenness of the leaf

552 measured (Limantara et al., 2015). Increased chlorophyll content in induced polyploids may show

553 increased photosynthesis rate (Wang et al., 2017; Rao et al., 2019). From these findings, the

554 mixoploid and octoploid leaves are predicted to have higher photosynthetic capacity due to their

555 higher SPAD value or higher content of chlorophyll. The improvement in SPAD value in polyploid

556 of $N$. cadamba signifies the importance of polyploidization as a plant breeding tool. The SPAD

557 value is not the sole factor that results in greater growth or yield of a crop. In wheat, the relationship

558 between SPAD value and grain productivities was studied (Monostori et al., 2016). They found

559 that other factors also affect the grain productivity, such as soil nitrogen content, cultivar and

560 environment. According to Kandel (2020), SPAD value and yield are not often collinearly related

561 as it may result from genetic variation, differential absorption strength in nitrogen, chlorophyll

562 biosynthesis and chlorophyll degradation.

563

564 Conclusions

565 To the best of our knowledge, this is the first report of polyploidization in N. cadamba. Our study

566 lays the foundation for producing octoploid and mixoploid plants of $N$. cadamba using an anti-

567 mitotic agent - colchicine. Both colchicine-induced polyploid plants are growing slower than

568 tetraploids under in vitro conditions. However, the leaves of octoploid plants have thicker leaf

569 blades, thicker midrib, lower stomata density and bigger stomata size. This indicates that octoploid

570 plants could respond better to environmental changes. These novel polyploid plants could be

571 beneficial for future genetic improvement of $N$. cadamba; for instance, octoploid could backcross

572 with tetraploid to produce a novel hexaploid plant $(2 \mathrm{n}=6 \mathrm{x}=66)$ or interploid. Hence, the in vitro 
573 colchicine-induced mutation could be a valuable breeding strategy of $N$. cadamba to produce

574 improved clones for planted forest development.

575

576

\section{Acknowledgements}

578 This study was supported by funding from the Sarawak Timber Association (STA) to Universiti 579 Malaysia Sarawak (UNIMAS). The Ministry of Education Malaysia is also acknowledged for 580 granting financial assistance to the first author. The authors would like to acknowledge WTK for 581 providing the plant materials for this research project.

582

583 Funding

584 The funding from the Sarawak Timber Association (STA) was awarded to the second author with 585 grant numbers GL(F07)/06/2013/STA-UNIMAS(06) and GL/F07/STA01/2019.

586

587 Competing Interests

588 The authors declare there are no competing interests.

589

590 Author Contributions

591 Eng, WH and Ho, WS designed the research project. Eng, WH performed the experiments and 592 analyzed data. Eng, WH and Ho, WS wrote the manuscript. Ho, WS and Ling, KH modified the 593 manuscript. All authors read and endorsed the final manuscript. 
595

596

597

598

599

600

601

602

603

604

605

606

607

608

609

610

611

612

613

614

615

616

617

618

619

620

621

622

623

624

625

626

627

628

629

630

631

632

633

634

635

636

637

638

639

\section{References}

Afzal, A., Duiker, S.W., \& Watson, J.E. (2017). Leaf thickness to predict plant water status. Biosystem Engineering, 156, 148-156.

Ahmed, B.A., Mohajer, S., Elnaiem, E.M., \& Taha, R.M. (2012). In vitro Regeneration, Acclimatization and Antimicrobial Studies of Selected Ornamental Plants. In Plant Science (Dhal, N.K., \& Sahu, S.C.), 255-274. London: IntechOpen.

Aleza, P., Juárez, J., Ollitrault, P., \& Navarro, L. (2009). Production of tetraploid plants of nonapomictic citrus genotypes. Plant Cell Reports, 28, 1837-1846.

Awadh, H.A.A, Abdulhussein, M.A.A., \& Almusawi, A.H.A. (2019). Effects of paclobutrazol and sucrose in date palm (Phoenix dactylifera 1.) micropropagation via direct organogenesis. Plant Archives, 19(1), 1130-1134.

Bedi, Y.S., Bir, S.S., \& Gill, B.S. (1981). Cytopalynology of woody taxa of family Rubiaceae from North and Central India. Proceeding Indian Natural Science Academy, B47(6), 708-715.

Bennett, M.D., Bhandol, P., \& Leitch, I.J. (2000). Nuclear DNA amounts in Angiosperms and their modern uses, 807 new estimates. Annals of Botany, 86(4), 859-909.

Bertolino, L.T., Caine, R.S., \& Gray, J.E. (2019). Impact of stomatal density and morphology on water-use efficiency in a changing world. Frontier Plant Science, 10, 225.

Bicknell, R., Boase, M., \& Morgan, E. (2019). Developing polyploid genotypes of Leptospermum scoparium. New Zealand Journal of Crop and Horticultural Science, 47(4) 273-281.

Camargo, M.A.B., \& Marenco, RA, (2011). Density, size and distribution of stomata in rainforest tree species in Central Amazonia. Acta Amozonica, 41(2), 205-212.

Chandra, S., Bandopadhyay, R., Kumar, V., \& Chandra, R. (2010). Acclimatization of tissue cultured plantlets: from laboratory to land. Biotechnology Letter, 32, 1199-1205.

Chen, C., Hou, X., Zhang, H., Wang, G., \& Tian, L. (2011). Induction of Anthurium andraeanum "Arizona" tetraploid by colchicine in vitro. Euphytica, 181, 137-145.

Comai, L. (2005). The advantages and disadvantages of being polyploid. Nature Reviews Genetics, $6,836-846$.

Coneva, V., \& Chitwood, D.H. (2018). Genetic and developmental basis for increased leaf thickness in the Arabidopsis cv ecotype. Frontiers in Plant Science, 9, 322.

Dar, T.H., Agrawal, R., Mir, B.A., \& Dar, G.H. (2013). Polyploidy: a tool that plants use to survive climate changes. Journal of Experimental Biology and Agricultural Sciences, 1(1), 13-15. 
640

641

642

643

644

645

646

647

648

649

650

651

652

653

654

655

656

657

658

659

660

661

662

663

664

665

666

667

668

669

670

671

672

673

674

675

676

677

678

679

680

681

682

683

684

685

Das, B.C., Prasad, D.N., \& Sikdar, A.K. (1970). Colchicine induced tetraploids of Mulberry. Caryologia, 23(3), 283-293.

de Alencar, L.D., Azevedo, P., \& Latado, R.R. (2020). Mothers' command: phenotypes changes resulting from reciprocal interploidy crosses. Euphytica, 216, 21.

Debergh, P.C. (1991). Acclimatization techniques of plants from in vitro. Acta Horticulture, 289, 291-300.

de Boer, H.J., Price, C.A., Wagner-Cremer, F., Dekker, S.C., Franks, P.J., \& Veneklaas, E.J. (2016). Optimal allocation of leaf epidermal area for gas exchange. New Phytologist, 210(4), 1219-1228.

Demtsu, B., Taychasinpitak, T., Wongchaochant, S., \& Manochai, B. (2013). Induced mutation by colchicine treatment of somatic embryos in 'Namwa' Banana (Musa sp. ABB). International Transaction Journal of Engineering, Management, \& Applied Sciences \& Technologies, 4(4), 311-320.

D'Hondt, L., Hofte, M., Van Bockstaele, E., \& Leus, L. (2011). Applications of flow cytometry in plant pathology for genome size determination, detection and physiological status. Molecular Plant Pathology, 12(8), 815-828.

Dittberner, H., Korte, A., Mettler-Altmann, T., Weber, A.P.M., Monroe, G., \& de Meaux, J. (2018). Natural variation in stomata size contributes to the local adaptation of water-use efficiency in Arabidopsis thaliana. Molecular Ecology, 20(27), 4052-4065.

Doheny-Adams, T., Hunt, L., Franks, P.J., Beerling, D.J., \& Gray, J.E. (2012). Genetic manipulation of stomatal density influences stomatal size, plant growth and tolerance to restricted water supply across a growth carbon dioxide gradient. Philosophical Transactions Royal Society Botany, 367(1588), 547-555.

Doležel, J., Binarová, P., \& Lucretti, S. (1989). Analysis of nuclear DNA content in plant cells by flow cytometry. Biologia Plantarum, 31(2), 113-120.

Doležel, J., Greilhuber, J., \& Suda, J. (2007). Flow Cytometry with Plants: An Overview. In Flow Cytometry with Plant Cells Analysis of Genes, Chromosomes and Genomes (Doležel, J.), pp. 41-65. Germany: Wiley-VCH Verlag GmbH \& Co.

Doyle, J.J., \& Coate, J.E. (2019). Polyploidy, the nucleotype, and novelty: the impact of genome doubling on the biology of the cell. International Journal of Plant Science, 180(1), 1-52.

Dudits, D., Török, K., Cseri, A., Paul, K., Nagy, A.V., Nagy, B., Sass, L., Ferenc, G., Vankova, R., Dobrev, P., Vass, I., \& Ayaydin, F. (2016). Response of organ structure and physiology to autotetraploidization in early development of energy willow Salix viminalis. Plant Physiology, 170, 1504-1523. 
686 Eigsti, O.J., \& Dustin, A.P. (1956). Colchicine in agriculture, medicine. The Homœopathic

687

688

689

690

691

692

693

694

695

696

697

698

699

700

701

702

703

704

705

706

707

708

709

710

711

712

713

714

715

716

717

718

719

720

721

722

723

724

725

726

727

728

729

Recorder, 22, 1-3.

Eng, W.H., \& Ho, W.S. (2019). Polyploidization using colchicine in horticultural plants: A review. Scientia Horticulturae, 246, 604-617.

Eng, W.H., Ho, W.S., \& Ling, K.H. (2020). Chromosome count improvement and digitalization of Neolamarckia cadamba. Research Square. Doi: 10.21203/rs.3.rs-90777/v1

Fu, D., Xiao, M., Hayward, A., Fu, Y., Liu, G., Jiang, G., \& Zhang, H. (2014). Utilization of crop heterosis: a review. Euphytica, 197, 161-173.

Ghanbari, M.A., Jowkar, A., Salehi, H., \& Zarei, M. (2019). Effects of polyploidization on petal characteristics and optical properties of Impatiens walleriana (Hook.). Plant Cell, Tissue and Organ Culture, 138, 299-310.

Gimenes, R., Pivetta,K.F.L., Mazzini-Guedes, R.B., Ferraz, M.V., Pereira, S.T.S., Santos, Á.S., de Faria, R.T., \& de Almeida, L.C.P. (2018). Paclobutrazol on in vitro growth and development of Zygopetalum crinitum Orchid, and on seedling acclimatization. American Journal of Plant Sciences, 9(5), 1029-1036.

Godfree, R.C., Marshall, D.J., Young, A.G., Miller, C.H., \& Mathews, S. (2017). Empirical evidence of fixed and homeostatic patterns of polyploid advantage in a keystone grass exposed to drought and heat stress. Royal Society Open Science, 4(11), 170934.

Grosser, J.W., Kainth, D., \& Dutt, M. (2014). Production of colchicine-induced autotetraploids in Pummelo (Citrus grandis osbeck) through indirect organogenesis. Hortscience, 49(7), 944948.

Hammond, J., Cai, D., \& Verhey, K.J. (2008). Tubulin modifications and their cellular functions. Current Opinion in Cell Biology, 20(1), 71-76.

Hassan, J., Miyajima, I., Ozaki, Y., Mizunoe, Y., Sakai, K., \& Zaland, W. (2020). Tetraploid induction by colchicine treatment and crossing with a diploid reveals less-seeded fruit production in pointed gourd (Trichosanthes dioica Roxb.). Plants, 9(3), 370.

Ho, W.S., Pang, S.L., \& Julaihi, A. (2014). Identification and analysis of expressed sequence tags present in xylem tissues of Kelampayan (Neolamarckia cadamba (Roxb.) Bosser). Physiology and Molecular Biology of Plants, 20(3): 393-397.

Ho, W.S., Ling, K.H., \& Pang, S.L. (2020). Silviculture, Genetics and Molecular Breeding of Neolamarckia cadamba (Kelampayan) in Sarawak. UNIMAS Publisher. 220p. ISBN: 978967-2298-28-1.

Peer) reviewing PDF | (2021:06:62624:1:0:NEW 15 Sep 2021) 
730

731

732

733

734

735

736

737

738

739

740

741

742

743

744

745

746

747

748

749

750

751

752

753

754

755

756

757

758

759

760

761

762

763

764

765

766

767

768

769

770

771

772

773

774

Huang, R., Liu, D., Zhao, M., Li, Z., Li, M., \& Sui, S. (2015). Artificially induced polyploidization in Lobularia maritima (L.) Desv. and its effect on morphological traits. HortScience, 50(5), 636-639.

Huy, N.P. Tam, D.T.T., Luan, V.Q., Tung, H.T., Hien, V.T., Ngan, H.T.M., Duy, P.N., \& Nhut, D.T. (2019). In vitro polyploid induction of Paphiopedilum villosum using colchicine. Scientia Horticulturae, 252, 283-290.

Inoue, S. (1952). The effect of colchicine on the microscopic and submicroscopic structure of the mitotic spindle. Experimental Cell Research, 2, 305-318.

Inthima, P., \& Sujipuli, K. (2019). Improvement of growth and bacoside production in Bacopa monnieri through induced autotetraploidy with colchicine. PeerJ 7:e7966 http://doi.org/10.7717/peerj.7966.

Javadian, N., Karimzadeh, G., Sharifi, M., Moieni, A., \& Behmanesh, M. (2017). In vitro polyploidy induction: changes in morphology, podophyllotoxin biosynthesis, and expression of the related genes in Linum album (Linaceae). Planta, 245(6), 1165-1178.

Jiang, Y., Liu, S., Hu, J., He, G., Liu, Y., Chen, X., Lei, T., Li, Q., Yang, L., Li, W., Hu, D., Li, J., \& Gao, S. (2020). Polyploidization of Plumbago auriculata Lam. in vitro and its characterization including cold tolerance. Plant Cell, Tissue and Organ Culture, 140, 315325.

Jøker, D. (2000). Neolamarckia cadamba. Seed Leaflet 17. Denmark: Danida Forest Seed Centre.

Julião, S.A., Ribeiro, C.d.V., Lopes, J.M.L., Matos, E.M.d., Reis, A.C., Peixoto, P.H.P., Machado, M.A., Azevedo, A.L.S., Grazul, R.M., Campos, J.M.S.D., \& Viccini, L.F. (2020). Induction of synthetic polyploids and assessment of genomic stability in Lippia alba. Frontiers in Plant Science, 11, 1-11.

Kandel, B.P. (2020). SPAD value varies with age and leaf of maize plant and its relationship with grain yield. BMC Research Notes, 13, 1-4.

Kienh, M., \& Lorence, D.H. (1996). Chromosome counts on Angiosperms cultivated at the National Tropical Botanical Garden, Kauai, Hawaii. Pacific Science, 50(3), 317-323.

Kim, J.S., Seo, M.S., Moon, M.S., Won, S.Y., \& Kwon, S.J. (2019). Insight on doubled haploid production with an amphidiploid Species 'Dolsangat' in Brassica juncea. Korean Jounal of Breeding Science, 51(4), 341-350.

Krishnapillay, D.B., Razak, M.A.A., \& Appanah, S. (2007). Forest Rehabilitation - The Malaysian Experience. In Keep Asia Green Volume I Southeast Asia (Lee, K.D.), pp. 85-123. Vienna: International Union of Forest Research Organizations.

Peer) reviewing PDF | (2021:06:62624:1:0:NEW 15 Sep 2021) 
775

776

777

778

779

780

781

782

783

784

785

786

787

788

789

790

791

792

793

794

795

796

797

798

799

800

801

802

803

804

805

806

807

808

809

810

811

812

813

814

815

816

817

818

819

820

Krisnawati, H., Kallio, M., \& Kanninen, M. (2011). Anthocephalus cadamba Miq. - Ekologi, Silvikultur dan Produktivitas. Indonesia: Centre for International Forest Research.

Lal, M., Dutt, D., Tyagi, C.H., Upadhyay, J.S., \& Upadhyay, S. (2010). Characterization of Anthocephalus cadamba and its delignification by kraft pulping. TAPPI Journal, 9, 30-37.

Li, S., Lin, Y., Pei, H., Zhang, J., Zhang, J., \& Luo, J. (2020). Variations in colchicine-induced autotetraploid plants of Lilium davidii var. unicolor. Plant Cell, Tissue and Organ Culture, $141,479-488$.

Li, Q., Deng, M., Xiong, Y., Coombes, A., \& Zhao, W. (2014). Morphological and photosynthetic response to high and low irradiance of Aeschynanthus longicaulis. Scientific World Journal, 2014, 1-8.

Lim, S.C., \& Chung, R.C.K. (2002). A Dictionary of Malaysian Timber. Kuala Lumpur, Forest Research Institute.

Limantara L., Dettling, M., Indrawati, R., Indriatmoko, \& Brotosudarmo, T.H.P. (2015). Analysis on the chlorophyll content of commercial green leafy vegetables. Procedia Chemistry, 14, 225-231.

Lu, Y., Chen, J., Xiao, M., Li, W., \& Miller, D.D. (2012). An overview of tubulin inhibitors that interact with the colchicine binding site. Pharmaceutical Research, 29(11), 2943-2971.

Mansur, I., \& Tuheteru, F.D. (2010). Kayu Jabon. Indonesia: PT Niaga Swadaya.

Martin, C., Viruel, M.A., Lora, J., \& Hormaza, J.I. (2019). Polyploidy in Fruit Tree Crops of the Genus Annona (Annonaceae). Frontiers in Plant Science, 10, 99.

Mengesha, A., Ayenew, B., \& Tadesse, T. (2013). Acclimatization of in vitro propagated pineapple (Ananas comosuss (L.), var. Smooth cayenne) plantlets to ex vitro condition in Ethiopia. American Journal of Plant Sciences, 4(2), 317-323.

Mok, P.K., \& Ho, W.S. (2019). Rapid in vitro propagation and efficient acclimatisation protocols of Neolamarckia cadamba. Asian Journal of Plant Sciences, 18(4), 1-11.

Mondal, S., Dash, G.K., Acharyya, A., Acharyya, S., \& Sharma, H.P. (2009). Studies on diuretic and laxative activity of bark extracts of Neolamarckia cadamba (Roxb.) Bosser. Drug Invention Today, 1(1), 78-80.

Monostori, I., Árendás, T., Hoffman, B., Galiba, G., Gierczik, K., Szira, F., \& Vágújfalvi, A. (2016). Relationship between SPAD value and grain yield can be affected by cultivar, environment and soil nitrogen content in wheat. Euphytica, 211, 103-112.

Nordahlia, A.S., Lim, S.C., Hamdan, H., \& Anwar, U.M.K. (2014). Wood properties of selected plantation species: Tectona grandis (Teak), Neolamarckia cadamba (Kelempayan/Laran),

Peer] reviewing PDF | (2021:06:62624:1:0:NEW 15 Sep 2021) 
Octomeles sumatrana (Binuang) and Paraserianthes falcataria (Batai). Timber Technology Centre, 54, 1-8.

Ogburn, R., \& Edwards, E.J. (2010). The ecological water-use strategies of succulent plants. Advance Botany Research, 55, 179-225.

Ohri, D., Bhargava, A., \& Chatterjee, A. (2004). Nuclear DNA amounts in 112 species of tropical hardwood- New estimates. Plant Biology, 6(5), 555-561.

Orwa, C., Mutua, A., Kindt, R., Jamnadass, R., \& Anthony, S. (2009). Agroforestry tree database: a tree reference and selection guide version 4.0. Retrieved from http://www.worldagroforestry.org/treedb2/AFTPDFS/Anthocephalus_cadamba.pdf

Payne, W.W. (1978). A glossary of plant hair terminology. Brittonia, 30(2), 239-255.

Pham, P., Li, Y., Guo, H., Zeng, R., Xie, L., \& Zhang, Z. (2019). Changes in morphological characteristics, regeneration ability, and polysaccharide content in tetraploid Dendrobium officinale. HortScience, 54(11), 1879-1886.

Pospíšilová, J., Tichá, I., Kadleček, P., Haisel, D., \& Plzáková, Š. (1999). Acclimatization of micropropagated plants to ex vitro conditions. Biologia Plantarum, 42(4), 481-497.

Puangsomlee, P., \& Puff, C. (2001). Chromosome numbers of Thai Rubiaceae. Nordic Journal of Botany, 21(2), 165-176.

Raghuvanshi, S.S., \& Joshi, S. (1964). Cytomorphological studies on the colchiploids of Capsicum frutescens L. Caryologia, 29(1), 61-78.

Rao, S., Kang, X., Li, J., \& Chen, J. (2019). Induction, identification and characterization of tetraploidy in Lycium ruthenicum. Breeding Science, 69(1), 160-168.

Ravandi, G.E., Rezanejad, F., \& Dehghan, E. (2014). In vitro regeneration ability of diploid and autotetraploid plants of Cichorium intybus L. Cytology and Genetics, 48(3), 166-170.

Regalado, J.J., Carmona-Martín, E., Castro, P., Moreno, R., Gil, J., \& Encina, C.L. (2015). Study of the somaclonal variation produced by different methods of polyploidization in Asparagus officinalis L. Plant Cell, Tissue and Organ Culture, 122, 31-44.

Regalado, J.J., Carmona-Martín, E., Querol, V., Veléz, C.G., Encina, C.L., \& Pitta-Alvare, S.I. (2017). Production of compact petunias through polyploidization. Plant Cell, Tissue and Organ Culture, 129, 61-71.

Ribeiro, P.C., Souza, M.L., Muller, L.A.C., Ellis, V.A., Heuertz, M., Lemos-filho, J., \& Lovato, M.B. (2016). Climatic drivers of leaf traits and genetic divergence in the tree Annona crassiflora: a broad spatial survey in the Brazilian savannas. Global Change Biology, 22(11), 3789-3803. 
867

868

869

870

871

872

873

874

875

876

877

878

879

880

881

882

883

884

885

886

887

888

889

890

891

892

893

894

895

896

897

898

899

900

901

902

903

904

905

906

907

908

909

910

911
Sattler, M.C., Carvalho, C.R., \& Clarindo, W.R. (2016). The polyploidy and its key role in plant breeding. Planta, 243, 281-296.

Sen, N.K., \& Marimuthu, K.M. (1960). Colchiploids of Dolichos lablab L. Caryologia, 13(2), 411-429.

Shmeit, Y.H., Fernandez, E., Novy, P., Kloucek, P., Orosz, M., \& Kokoska, L. (2020). Autopolyploidy effect on morphological variation and essential oil content in Thymus vulgaris L. Scientia Horticulturae, 263, 109095.

Sinski, I., Bosco, D.D., Pierozzi, N.I., Maia, J.D.G., Ritschel, P.S., \& Quecini, V. (2014). Improving in vitro induction of autopolyploidy in grapevine seedless cultivars. Euphytica, 196, 299-311.

Soltis, P.S., Marchant, D.B., van de Peer, Y., \& Soltis, D.E. (2015). Polyploidy and genome evolution in plants. Current Opinion in Genetics and Development, 35, 119-125.

Soudzilovskaia, N.A., Elumeeva, T.G., Onipchenko, V.G., Shidakov, I.I., Salpagarovad, F.S., Khubievd A.B., Tekeev, D.K., \& Cornelissen, J.H.C. (2013). Functional traits predict relationship between plant abundance dynamic and long-term climate warming. $P N A S$, 110(45), 18180-18184.

Souza, M.L., Duarte, A.A., Lovato, M.B., Fagundes, M., Valladares, F., \& Lemos-Filho, J.P. (2018). Climatic factors shaping intraspecific leaf trait variation of a neotropical tree along a rainfall gradient. PLoS ONE, 13(12): e0208512.

Talbot, M.J., \& White, R.G. (2013). Methanol fixation of plant tissue for Scanning Electron Microscopy improves preservation of tissue morphology and dimensions. Plant Methods, 9 , $1-7$.

Thao, N.T.P., Ureshino, K., Miyajima, I., Ozaki, Y., \& Okubo, H. (2003). Induction of tetraploids in ornamental Alocasia through colchicine and oryzalin treatments. Plant Cell, Tissue and Organ Culture, 72, 19-25.

Tian, M., Yu, G., He, N., \& Hou, J. (2016). Leaf morphological and anatomical traits from tropical to temperate coniferous forests: Mechanisms and influencing factors. Scientific Reports, 6 , $1-10$.

Tsukaya, H. (2008). Controlling size in multicellular organs: Focus on the leaf. PLoS Biology, $6(7)$, e 174.

Urwin, N.A.R. (2014). Generation and characterisation of colchicine-induced polyploid Lavandula x intermedia. Euphytica, 197, 331-339. 
912 Wang, J., Li, D., Shang, F., \& Kang, X. (2017). High temperature-induced production of

913

914

915

916

917

918

919

920

921

922

923

924

925

926

927

928

929

930

931

932

933

934

935

936

937

938

939

940

941

942

943

944

945

946

947

948

949

950

951

952

953

954

955

956 unreduced pollen and its cytological effects in Populus. Scientific Reports, 7, 1-10.

Wang, W.D., Chang-Yi Wu, C.Y., \& Lonameo, B.K. (2019). Toxic effects of paclobutrazol on developing organs at different exposure times in Zebrafish. Toxics, 7, 1-14.

Wang, X., Cheng, Z., Zhi, S., \& Xu, F. (2016). Breeding triploid plants: A review. Czech Journal of Genetics and Plant Breeding, 52(2), 41-54.

Werker, E. (2000). Trichome diversity and development. In Plant Trichomes (Hallahan, D.L., \& Gray J.C.), 1-35. United States: Academic Press.

Widoretno, W. (2016). In vitro induction and characterization of tetraploid Patchouli (Pogostemon cablin Benth.) plant. Plant Cell, Tissue and Organ Culture, 125, 261-267.

Willmer, C., \& Fricker, M. (1996). The structure and development of stomata. Dordrecht: Springer.

Wu, J.H., Ferguson, A.R., Murray, B.G., Jia, Y., Datson, P.M., \& Zhang, J. (2012). Induced polyploidy dramatically increases the size and alters the shape of fruit in Actinidia chinensis. Annals of Botany, 109(1), 169-179.

Xiao, K., Mao, X., Lin, Y., Xu, H., Zhu, Y., Cai, Q., Xie, H., \& Zhang, J. (2017). Trichome, a functional diversity phenotype in plant. Molecular Biology, 6, 1-14.

Xie, X., Aguero, C.B., Wang, Y., \& Walker, M.A. (2015). In vitro induction of tetraploids in Vitis x Muscadinia hybrids. Plant Cell, Tissue and Organ Culture, 122, 675-683.

Yang, N., Rong, E., Li, Q., Dong, J., Du, T., Zhao, X., \& Wu, Y. (2015). Tetraploid induction and identification of Gossypium arboreum. Agricultural Sciences, 6(4), 436-444.

Zanzibar, M., \& Danu, (2015). Aplikasi Iradiasi Sinar Gamma untuk Peningkatan Produktivitas Tanaman Jabon Putih. In Bunga Rampai Teknologi Pembenihan dan Pembibitan Jabon Putih (Neolamarckia cadamba (Roxb.) Bosser) (Mindawati, N., Mansur, I., \& Setio, P.), pp. 137-157. Indonesia: Forda.

Zayed, Z.M., Ho, W., Pang, S., \& Ahmad, F.B. (2014). EMS-induced mutagenesis and DNA polymorphism assessment through ISSR markers in Neolamarckia cadamba (kelampayan) and Leucaena leucocephala (petai belalang). European Journal of Experimental Biology, 4(4), 156-163.

Zhang, X., \& Gao, J. (2020). Colchicine-induced tetraploidy in Dendrobium cariniferum and its effect on plantlet morphology, anatomy and genome size. Plant Cell, Tissue and Organ Culture. Doi:10.1007/s11240-020-01966-4 
957 Zhou, H.W., Zeng, W.D., \& Yan, H.B. (2017). In vitro induction of tetraploids in cassava variety 958 Xinxuan 048' using colchicine. Plant Cell, Tissue and Organ Culture, 28, 723-729.

959

960

961

962

963 


\section{Table $\mathbf{1}$ (on next page)}

Table 1 Polyploidization rate of nodal segments of $N$. cadamba using different colchicine concentrations and treatment durations.

Figures in parentheses represent the percentage of corresponding figures. 
Table 1 Polyploidization rate of nodal segments of $N$. cadamba using different colchicine concentrations and treatment durations.

\begin{tabular}{|c|c|c|c|c|c|c|}
\hline $\begin{array}{c}\text { Colchicine } \\
(\%, w / v)\end{array}$ & $\begin{array}{c}\text { Treatment } \\
\text { duration }(h)\end{array}$ & $\begin{array}{c}\text { Number of } \\
\text { explants }\end{array}$ & $\begin{array}{c}\text { Number of } \\
\text { surviving explants }\end{array}$ & $\begin{array}{c}\text { Number of } \\
\text { tetraploids }(\%)\end{array}$ & $\begin{array}{c}\text { Number of } \\
\text { mixoploids }(\%)\end{array}$ & $\begin{array}{c}\text { Number of } \\
\text { octoploids (\%) }\end{array}$ \\
\hline \multirow[t]{2}{*}{0.0} & 24 & 30 & $27(90.0)$ & $27(90.0)$ & $0(0.0)$ & $0(0.0)$ \\
\hline & 48 & 30 & $20(66.7)$ & $20(66.7)$ & $0(0.0)$ & $0(0.0)$ \\
\hline \multirow[t]{2}{*}{0.1} & 24 & 30 & $18(60.0)$ & $16(53.3)$ & $2(6.7)$ & $0(0.0)$ \\
\hline & 48 & 30 & $16(53.3)$ & $11(36.7)$ & $2(6.7)$ & $3(10.0)$ \\
\hline \multirow[t]{2}{*}{0.3} & 24 & 30 & $14(46.7)$ & $6(20.0)$ & $6(20.0)$ & $2(6.7)$ \\
\hline & 48 & 30 & $12(40.0)$ & $4(13.3)$ & $2(6.7)$ & $6(20.0)$ \\
\hline \multirow[t]{2}{*}{0.5} & 24 & 30 & $8(26.7)$ & $2(6.7)$ & $1(3.3)$ & $5(16.7)$ \\
\hline & 48 & 30 & $7(23.3)$ & $0(0.0)$ & $1(3.3)$ & $6(20.0)$ \\
\hline
\end{tabular}




\section{Table 2 (on next page)}

Table 2 In vitro shoot regeneration, growth, rooting and acclimatization of tetraploids, mixoploids and octoploids of $N$. cadamba.

For each parameter, means with different letters indicate significantly different at $5 \%$ level of probability using Duncan's test $(p<0.05)$. 
1

2

3

4 5

6

Table 2 In vitro shoot regeneration, growth, rooting and acclimatization of tetraploids, mixoploids and octoploids of N. cadamba.

\begin{tabular}{lccc}
\hline Morphological characteristics & Tetraploid & Mixoploid & Octoploid \\
\hline Regeneration & & & \\
Number of shoots \pm SE & $5.4 \pm 0.1^{\mathrm{b}}$ & $4.3 \pm 0.2^{\mathrm{a}}$ & $4.2 \pm 0.3^{\mathrm{a}}$ \\
Regeneration $(\%) \pm \mathrm{SE}$ & $94.4 \pm 5.6^{\mathrm{b}}$ & $100.0 \pm 0.0^{\mathrm{b}}$ & $83.3 \pm 0.0^{\mathrm{a}}$
\end{tabular}

\section{Growth}

Stem height $(\mathrm{cm}) \pm \mathrm{SE}$

$7.2 \pm 0.0^{\mathrm{c}}$

$6.8 \pm 0.0^{\mathrm{b}}$

$4.4 \pm 0.4^{\mathrm{a}}$

Number of leaves $\pm \mathrm{SE}$

$12.8 \pm 0.2^{\mathrm{a}}$

$12.9 \pm 0.2^{\mathrm{a}}$

$13.0 \pm 0.3^{\mathrm{a}}$

Number of nodes $\pm \mathrm{SE}$

$6.4 \pm 0.1^{\mathrm{a}}$

$6.4 \pm 0.1^{\mathrm{a}}$

$6.5 \pm 0.0^{\mathrm{a}}$

Stem diameter $(\mathrm{mm}) \pm \mathrm{SE}$

$2.3 \pm 0.1^{\mathrm{a}}$

$2.7 \pm 0.1^{\mathrm{b}}$

$2.9 \pm 0.1^{\mathrm{b}}$

\section{Rooting}

Root length $(\mathrm{cm}) \pm \mathrm{SE}$

$\begin{array}{ccc}1.8 \pm 0.1^{\mathrm{c}} & 1.6 \pm 0.0^{\mathrm{b}} & 1.4 \pm 0.0^{\mathrm{a}} \\ 13.8 \pm 0.9^{\mathrm{b}} & 16.1 \pm 0.5^{\mathrm{b}} & 11.1 \pm 0.7^{\mathrm{a}} \\ 100.0 \pm 0.0^{\mathrm{a}} & 100.0 \pm 0.0^{\mathrm{a}} & 100.0 \pm 0.0^{\mathrm{a}}\end{array}$

Number of roots $\pm \mathrm{S}$
Rooting $(\%) \pm \mathrm{SE}$

$100.0 \pm 0.0^{\mathrm{a}}$

$100.0 \pm 0.0^{\mathrm{a}}$

$100.0 \pm 0.0^{\mathrm{a}}$

\section{Acclimatization percentage}

Jiffy-7 \pm SE

Loamy soil $\pm \mathrm{SE}$

Loamy soil : Compost 1:3 $\pm \mathrm{SE}$
$94.4 \pm 5.6^{\mathrm{b}}$

$88.9 \pm 5.6^{\mathrm{b}}$

$50.0 \pm 9.6^{\mathrm{a}}$
$94.4 \pm 5.6^{\mathrm{b}}$

$94.4 \pm 5.6^{\mathrm{b}}$

$61.1 \pm 5.6^{\mathrm{a}}$
$94.4 \pm 5.6^{\mathrm{b}}$

$88.9 \pm 5.6^{\mathrm{b}}$

$66.7 \pm 0.0^{\mathrm{a}}$

For each parameter, means with different letters indicate significantly different at $5 \%$ level of probability using Duncan's test $(\mathrm{p}<0.05)$. 


\section{Table 3(on next page)}

Table 3 Morphological characteristics and SPAD values.

For each parameter, means with different letters indicate significantly different at $5 \%$ level of probability using Duncan's test $(p<0.05)$. 
4 Table 3 Morphological characteristics and SPAD values.

\begin{tabular}{lccc}
\hline Characteristics & Tetraploid & Mixoploid & Octoploid \\
\hline Leaf thickness & & & \\
Leaf thickness $(\mu \mathrm{m}) \pm \mathrm{SE}$ & $160.8 \pm 38.5^{\mathrm{a}}$ & $197.0 \pm 8.7^{\mathrm{ab}}$ & $247.2 \pm 15.0^{\mathrm{b}}$ \\
Midrib vertical thickness $(\mu \mathrm{m}) \pm \mathrm{SE}$ & $666.6 \pm 25.0^{\mathrm{a}}$ & $762.4 \pm 38.1^{\mathrm{ab}}$ & $831.7 \pm 61.7^{\mathrm{c}}$ \\
Midrib horizontal thickness $(\mu \mathrm{m}) \pm \mathrm{SE}$ & $616.2 \pm 42.1^{\mathrm{a}}$ & $793.0 \pm 48.5^{\mathrm{b}}$ & $899.1 \pm 56.0^{\mathrm{b}}$ \\
& & & \\
Stomata and trichome & & & \\
Stomata density $\left(\mathrm{mm}^{-2}\right) \pm \mathrm{SE}$ & $426.7 \pm 9.4^{\mathrm{b}}$ & $298.2 \pm 6.3^{\mathrm{a}}$ & $301.8 \pm 10.9^{\mathrm{a}}$ \\
Trichome density $\left(\mathrm{mm}^{-2}\right) \pm \mathrm{SE}$ & $33.9 \pm 4.0^{\mathrm{b}}$ & $4.9 \pm 2.0^{\mathrm{a}}$ & $4.9 \pm 2.7^{\mathrm{a}}$ \\
Stomata length $(\mu \mathrm{m}) \pm \mathrm{SE}$ & $25.3 \pm 0.2^{\mathrm{a}}$ & $29.3 \pm 0.3^{\mathrm{b}}$ & $30.7 \pm 0.3^{\mathrm{c}}$ \\
Stomata width $(\mu \mathrm{m}) \pm \mathrm{SE}$ & $14.9 \pm 0.2^{\mathrm{a}}$ & $16.1 \pm 0.2^{\mathrm{b}}$ & $16.6 \pm 0.2^{\mathrm{b}}$ \\
& & & \\
Stem cross-section & & & \\
Bark $(\mathrm{mm}) \pm \mathrm{SE}$ & $0.4 \pm 0.1^{\mathrm{a}}$ & $0.4 \pm 0.1^{\mathrm{a}}$ & $0.3 \pm 0.0^{\mathrm{a}}$ \\
Wood $(\mathrm{mm}) \pm \mathrm{SE}$ & $3.1 \pm 0.3^{\mathrm{a}}$ & $3.7 \pm 0.3^{\mathrm{a}}$ & $3.8 \pm 0.3^{\mathrm{a}}$ \\
Pith $(\mathrm{mm}) \pm \mathrm{SE}$ & $5.7 \pm 0.3^{\mathrm{b}}$ & $5.2 \pm 0.1^{\mathrm{b}}$ & $3.6 \pm 0.2^{\mathrm{a}}$ \\
& & & \\
SPAD value & & & \\
SPAD $\pm \mathrm{SE}$ & $37.1 \pm 1.0^{\mathrm{a}}$ & $37.2 \pm 0.4^{\mathrm{a}}$ & $39.7 \pm 0.6^{\mathrm{b}}$ \\
& & &
\end{tabular}
For each parameter, means with different letters indicate significantly different at $5 \%$ level of probability using Duncan's test $(\mathrm{p}<0.05)$.


Figure 1

Figure 1 Polyploid plants detection using FCM and chromosome count of N. cadamba.

(A) FCM histogram for control or tetraploid plantlet $(2 n=4 x)$, (B) FCM histogram for mixoploid plantlet ( $2 n+4 n=4 x+8 x)$, (C) FCM histogram for octoploid plantlet ( $4 n=8 x$ ), (D) Tetraploid cell with 44 chromosomes (Bar $=5 \mu \mathrm{m}$ ) and (E) Octoploid cell of $N$. cadamba "Kestamas-19" with 88 chromosomes (Bar $=5 \mu \mathrm{m}$ ).
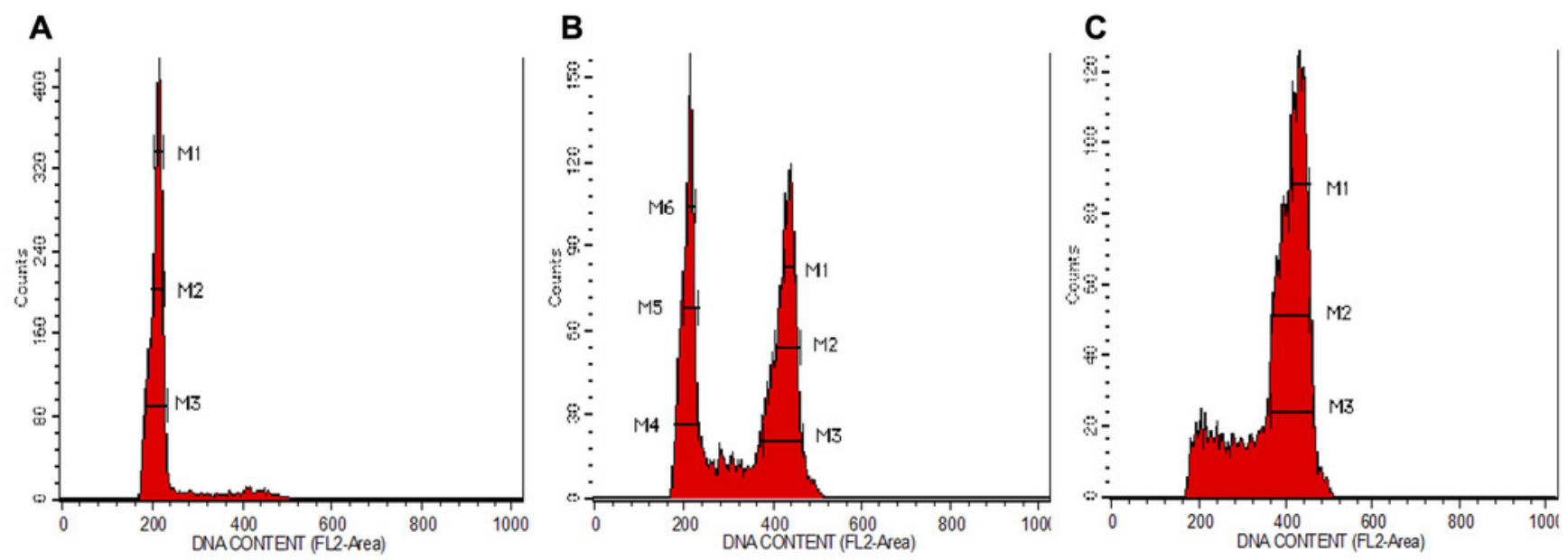

D

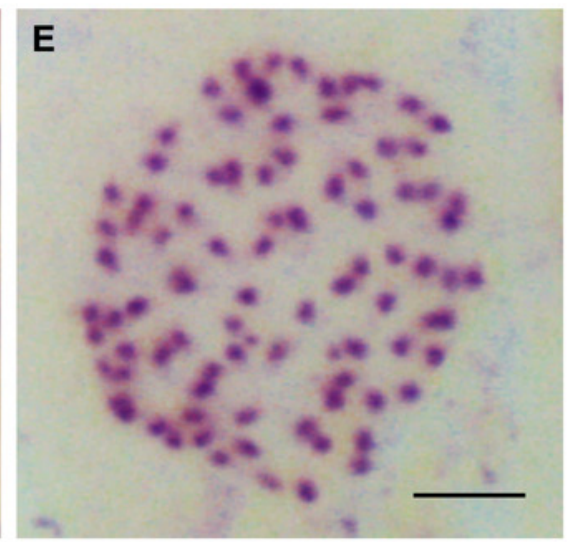




\section{Figure 2}

Figure 2 In vitro culture and acclimatization of $N$. cadamba polyploid plants.

Shoot regeneration of tetraploids (A), mixoploids (B) and octoploids (C). (D) Shoot tip growth of tetraploids (left), mixoploids (middle) and octoploids (right). Rooting of tetraploids (E), mixoploids $(F)$ and octoploids $(G)$. $(H)$ Acclimatization of plantlets $(T=$ Tetraploid, $M=$ Mixoploid, $\mathrm{O}=$ Octoploid) on different media ( $=$ Jiffy-7, $S=$ Soil, $C=$ Soil : Sompost $3: 1$ ), $($ Bar $=1 \mathrm{~cm})$. 

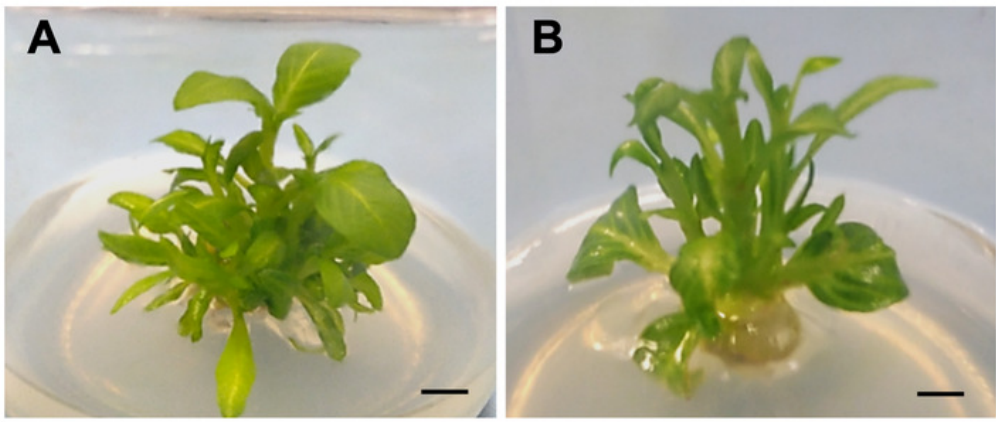

C
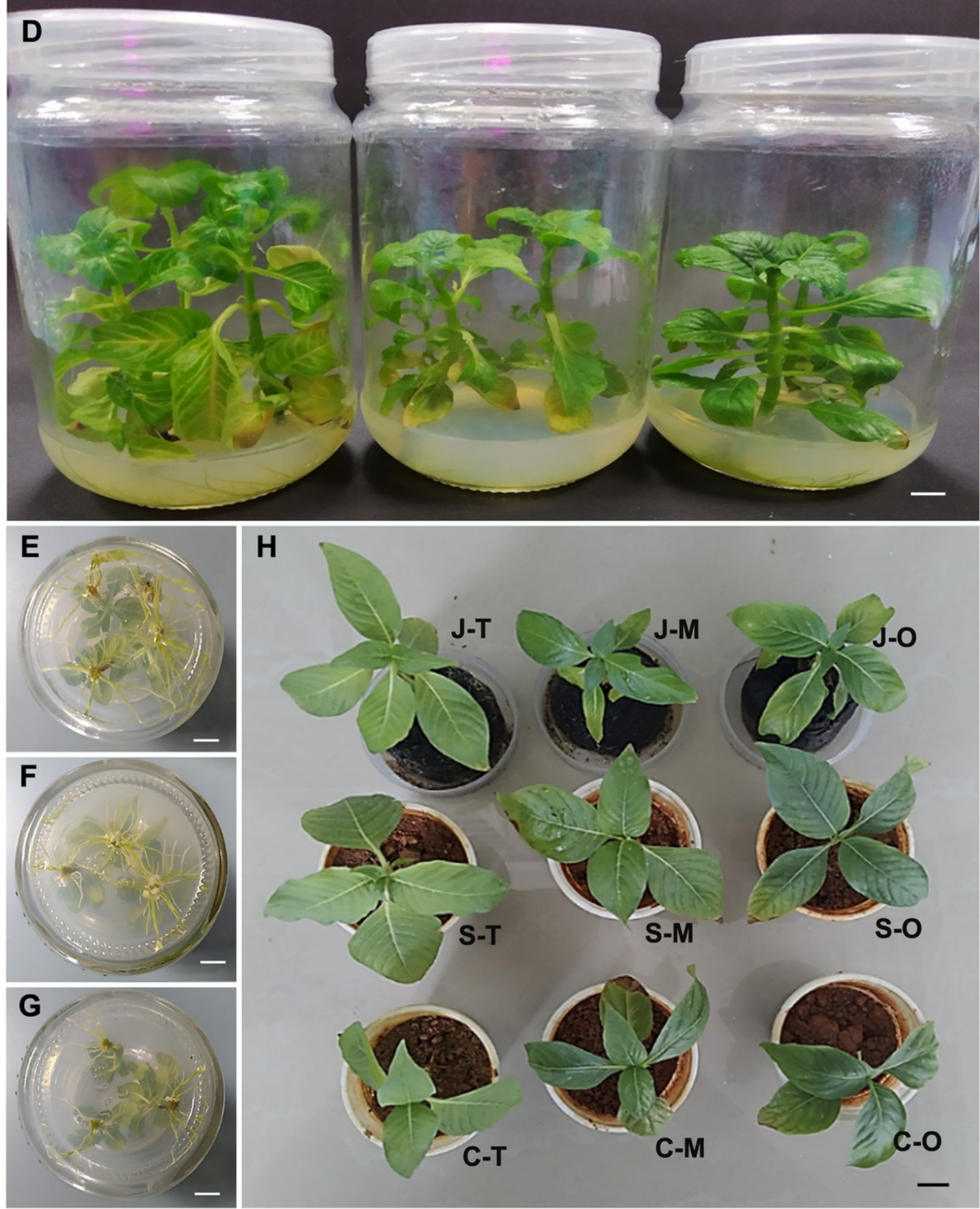


\section{Figure 3}

Figure 3 Morphological characteristics of N. cadamba polyploid plants.

Leaf sections of tetraploids (A), mixoploids (B) and octoploids (C). Stomata imprints of tetraploids $(D)$, mixoploids $(E)$ and octoploids $(F)$. Stoma micrographs of tetraploids $(G)$, mixoploids (H) and octoploids (I) under SEM. Trichome micrographs of tetraploids (J), mixoploids (K) and octoploids (L) under SEM. (M) Stem cross-section of tetraploids (left), mixoploids (middle) and octoploids (right) ( $b=$ bark; $w=$ wood; $p=$ pith). ( $T$ = Leaf thickness, $\mathrm{V}=$ Midrib vertical thickness, $\mathrm{H}=$ Midrib horizontal thickness) (Bar A-C $=0.5 \mathrm{~mm}$ ) (Bar D-F $=0.05 \mathrm{~mm}$ ). 

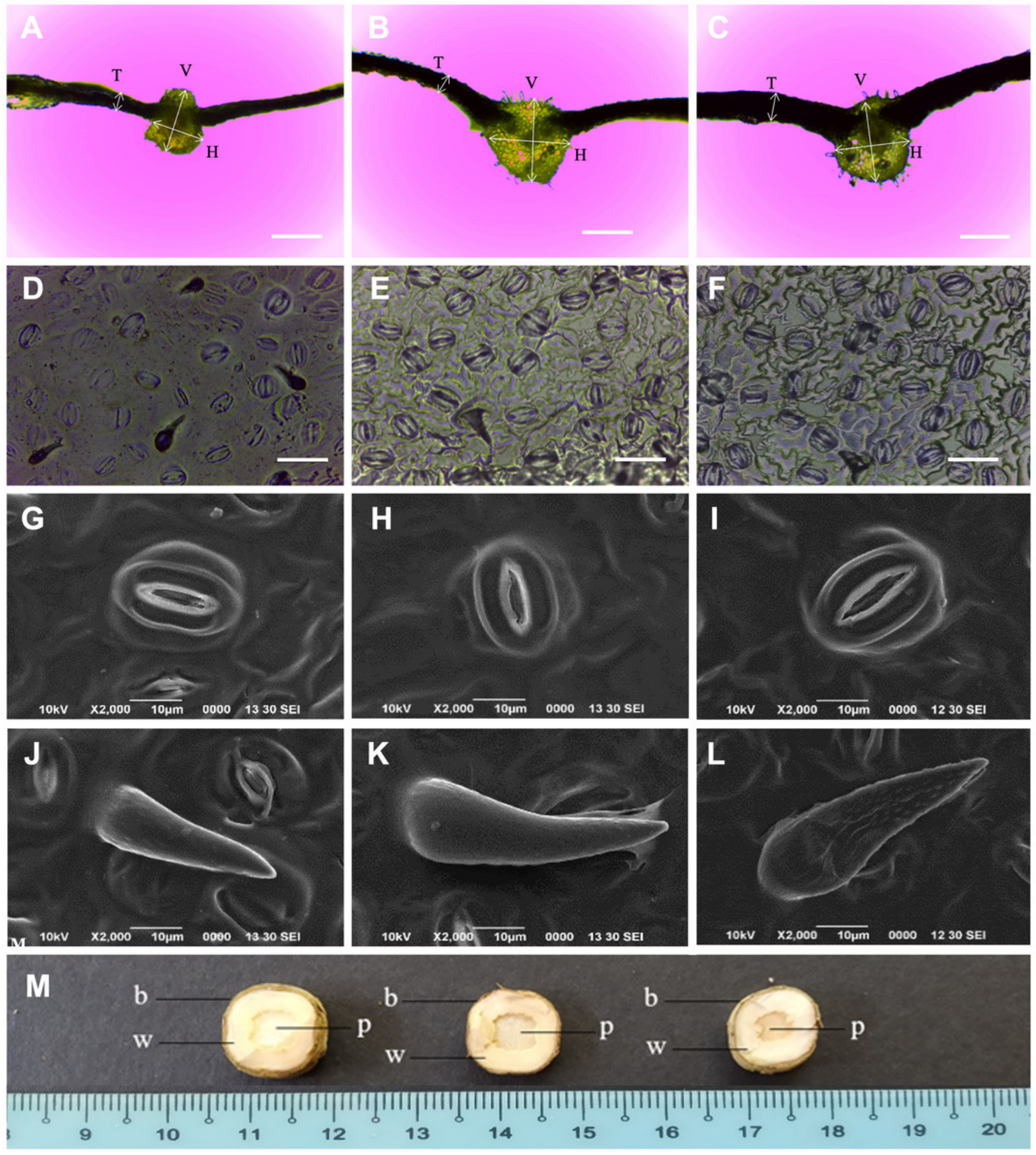